\title{
PHYSICAL DISABILITY AND PHYSICAL ACTIVITY: A REVIEW OF THE LITERATURE ON CORRELATES AND ASSOCIATIONS
}

\author{
Martin Saebu* \\ * Department of Coaching and Psychology, Norwegian School of Sport Sciences, Oslo, \\ Norway, and Beitostølen Healthsports Centre, Beitostølen, Norway
}

\begin{abstract}
The purpose of this article was to examine the literature on correlates and associations of physical activity among adults (age 16-65 years) with physical disabilities. Electronic searches were conducted to identify research articles published from 1980 to 2009. Specific inclusion criteria were identified. The search produced 4,189 articles; however, only 57 met all specified criteria. They represented seven different disability groups, including one cross-over category with two or more disabilities. The International Classification of Functioning, Disability and Health developed by the World Health Organization were used as a structural framework for organizing the results. The results revealed a substantial core of research concerning a few disability groups, among them spinal cord injury and multiple sclerosis. Significant correlates were identified in relation to type of disability and functioning, but also among environmental factors (e.g. costs, accessibility, built environment, information and social support) and personal factors (e.g. age, exercise self efficacy, depression, and mental health). Findings are discussed relative to conducting future physical activity research on persons with disabilities.
\end{abstract}

KEYWORDS: physical activity, exercise, disability, correlates, determinants

\section{INTRODUCTION}

Despite the huge amount of research that has been published in the field of exercise science over the past three decades, relatively little attention has been paid to physical activity behavior among people with a disability (Rimmer, Braddock, \& Pitetti, 1996). The health benefits and the impact on well-being (Heath \& Fentem, 1997; Physical Activity Guidelines Advisory Committee, 2008) are well documented, and it has even been claimed that for the health and wellbeing of people with a disability a physically active lifestyle is more important than for the general population (van der Ploeg, van der Beek, van der Woude, \& van Mechelen, 2004). In the past thirty years we have seen developments in research on physical activity and disability. During the eighties researchers were concerned about the health benefits of physical activity in persons with a disability and there was a call for training guidelines for

this population (e.g., Compton, Eisenman, \& Henderson, 1989). The public health perspective was still strong during the nineties (e.g., Heath \& Fentem, 1997), but an emerging interest for correlates, determinants and associations between physical activity and disability could be discerned (e.g., Kinne, Patrick, \& Maher, 1999).

In 1995, a study on physical activity and public health (Pate et al., 1995) sponsored by the Centers for Disease Control and Prevention (CDC) and The American College of Sports Medicine (ACSM), barely mentioned persons with physical disabilities. They were grouped along with older adults, the socioeconomically disadvantaged, and the less educated. The part of the report which cited data about the proportion of adults who did not engage in leisure time physical 
activity, categorized by gender, race, annual income, and education, did not include persons with disabilities (Rimmer et al., 1996).

However, 15 years later, there exists more knowledge about this population and also about various disability groups. In 2005, CDC reported that twice as many adults with a disability $(25,6 \%)$ were physically inactive during the preceding week, compared to adults without a disability $(12,8 \%)$ (Centers for Disease Control and Prevention, 2007). This was consistent with other studies from the U.S. (Boslaugh \& Andresen, 2006; Ellis, Kosma, Cardinal, Bauer, \& McCubbin, 2007; McGuire, Strine, Okoro, Ahluwalia, \& Ford, 2007; Rimmer, Rubin, \& Braddock, 2000). There is also an increasing amount of research connected to activity level and methods for measuring physical activity and exercise in this population (Cervantes \& Porretta, 2010; Washburn, Zhu, McAuley, Frogley, \& Figoni, 2002). Therefore, the aim of this review was to get an overview of the existing knowledgebase about correlates and associations of physical activity and disability.

\section{Selection of variables within the ICF factors}

Within the factor functioning and disability, there has been a call for research on potential differences in activity patterns between groups of people with different disabilities (Rimmer et al., 1996). Research indicates that the severity of the disability is negatively correlated with physical activity (Jahnsen, Villien, Aamodt, Stanghelle, \& Holm, 2003). Consequently, information about the type and the severity of the disability seems important to include. Furthermore, environmental barriers seem to limit participation in physical activity for people with disabilities (Rimmer, 2005; Rimmer, Wang, \& Smith, 2008). Consequently, information about environmental factors should be included to fully understand the correlates of physical activity. Environmental factors include physical environment factors, social and cultural correlates. In addition, Scelza, Kalpakjian, Zemper and Tate (2005) reported that lack of motivation, lack of energy, and lack of interest were the most frequently cited barriers to exercise among individuals with SCI, emphasizing that psychosocial aspects are important, too. Consequently, personal factors should be included, in a similar way as in research on able-bodied (Bauman, Sallis, Dzewaltowski, \& Owen, 2002). Personal factors include demographic-, biological-, psychological-, cognitive-, and emotional correlates. The correlates of environmental and personal factors were chosen based on similar research among able-bodied (Bauman et al., 2002; Trost, Owen, Bauman, Sallis, \& Brown, 2002).

In summary, the purpose of this paper is to provide a comprehensive review of the literature which examines (1) physical activity level and (2) correlates and associations of physical activity among adults with a disability, in relation to (a) functioning (b) environmental factors and (c) personal factors. Finally, (3) we will also examine the studies in relation to disability type.

\section{METHOD}

\section{General}

Scoping reviews are particularly important as an overview when a research area (such as disability and physical activity) does not have uniformity in study design and measurement (Hempel, Norman, Golder, Aguiar-Ibanez, \& Eastwood, 2008; Rimmer, Chen, McCubbin, Drum, \& Peterson, 2010). This type of review use specific protocols to increase focus in study identification, appraisal, and synthesis, thereby reducing bias (Petticrew \& Roberts, 2006). On this basis, the methodological approach of a scoping review was preferable.

\section{Literature search \\ PubMed,}

PsycINFO

and

SPORTdiscus were systematically searched for relevant articles. These databases were chosen because together they are generally acknowledged to provide a complete overview of studies and articles covering disability and physical activity/exercise, in relation to sport, psychology and 
rehabilitation. This is in line with previously conducted similar literature reviews (van der Ploeg et al., 2004). We specifically looked for studies describing the relationship between physical activity and disability. The keywords used in the Medline search were "exercise" (Medical Subject Headings term - MeSH including both "physical activity" and exercise) and disabled persons (MeSH term including disabled, disability, physically disabled, physically challenged, physically handicapped). PsycINFO was searched using "physical activity" or "exercise" and "disab*" to include disability, disabled and people with a disability. SPORTdiscus was searched using the terms "physical activity", "exercise", "motivation" and "disab*" to include disability, disabled and people with a disability.

\section{Selection criteria}

English language peer-reviewed primary literature that examined physical activity (or exercise) and disability among adults with disabilities was included in the review. Physical disability was defined as someone with a mobility or sensory impairment. Although important, cognitive, mental health and developmental disabilities were not included in this review. The search included articles about persons with a physical disability aged 18-65 years (excluding children and older adults), for the period from 1980-2009. The research before 1980 was limited and mostly described the health benefits of activity, and early experiences with physical activity and disability. Further, we excluded articles concerning physical activity in school and education, athletes with a disability, low back pain, and fibromyalgia. Due to the scope and complexity of the present review, studies testing theoretical models and constructs were also excluded. Keywords for the link between physical activity and persons with a disability were; determinants, associations, correlates, predictors, barriers, facilitators, and mediators. Search results are presented in Table 1.

Table 1. Search terms, publication year and results

\begin{tabular}{lllc}
\hline Database & Search terms & Publ. year & No. Citations \\
\hline PubMed & Disabled persons AND exercise & $1980-1989$ & 27 \\
& & $1990-1999$ & 162 \\
\multirow{2}{*}{ SPORTDiscus } & $2000-2009$ & 405 \\
& Disability AND physical activity & $1980-1989$ & 479 \\
& Disability AND exercise & $1990-1999$ & 752 \\
PsycINFO & & $2000-2009$ & 1560 \\
& Disability AND physical activity & $1980-1989$ & 17 \\
& Disability AND exercise & $1990-1999$ & 135 \\
\hline All databases & & $2000-2009$ & 652 \\
\hline
\end{tabular}

Article citations were excluded at the abstract level if they met the following exclusion criteria: not disability related, not physical activity or exercise related, sample based on athletes with a disability, descriptive articles or program descriptions, non-English language, published before 1980, all study participants younger than 18 years or older than 65 years, physical education/school and non-peer-reviewed publications (i.e., dissertations, chapters, non-peer-reviewed articles, and conference presentations). Reviews of the literature on outcomes of exercise interventions for persons with physical and cognitive disabilities have been conducted previously (Rimmer et al., 2010; Taylor, Baranowski, \& Young, 1998). The focus of most interventions have been on physical and mental health gains of physical activity in clinical or community practice, 
and less with correlates of existing physical activity. Rimmer et al. (2010) were for instance focusing on health outcomes (i.e., functional health, cardiorespiratory health, musculoskeletal health, metabolic health including healthy weight and mental health) of clinical exercise interventions. Therefore, intervention studies were excluded in the present paper.

The reason for excluding studies involving participants aged 65 years and older was to control for aging related factors that may attenuate the potential impact of the exercise interventions on younger individuals with disabilities. In conclusion, studies that met the following criteria were included: (1) cross sectional studies, prospective studies; qualitative studies (2) health outcomes (physical activity or disability) as dependent variables or discussion point; and, most importantly, (3) describing correlates, determinants, associations or mediators in relation to physical activity. 57 studies were included in the final analysis (see Table 2.)

\section{Data extraction and synthesis}

For studies that met the inclusion criteria, we extracted the data for each individual study by type of disability, research design, data collection method, type of independent variables (environmental, personal and function-related) and dependent variable. Type of disability was classified according to the participants' main diagnosis (1) Stroke; (2) Multiple Sclerosis; (3) Spinal cord injury; (4) Cerebral palsy; (5) Parkinson's disease; (6) Combined diagnosis or disability groups. The research design was classified into one of the following categories: (1) Cross-sectional studies and (2) Qualitative studies. Data collection method as listed under the following headings: (1) Postal questionnaire; (2) Telephone-interview questionnaire; (3); Internet-questionnaire; (4) In-depth interview (5) Focus-groups and (6) Combined (e.g., pedometer/accelerometer/ questionnaire). Types of exercise was also extracted, but yielded only limited information. Ninety percent of the activities
Table 2. Percent and number of physical activity studies by disability, research design, data collection method, and publication year

\begin{tabular}{|c|c|c|}
\hline Characteristic & $N$ & $\%$ \\
\hline \multicolumn{3}{|l|}{ Disability } \\
\hline Stroke & 1 & 1,8 \\
\hline MS & 9 & 15,8 \\
\hline SCI & 12 & 21,0 \\
\hline $\mathrm{CP}$ & 5 & 8,8 \\
\hline Parkinson & 1 & 1,8 \\
\hline Heterogeneous & 29 & 50,8 \\
\hline Sum & 57 & 100,0 \\
\hline \multicolumn{3}{|l|}{ Research design } \\
\hline Cross sectional & 42 & 73,7 \\
\hline Qualitative & 15 & 26,3 \\
\hline Sum & 57 & 100,0 \\
\hline \multicolumn{3}{|l|}{ Data collection method } \\
\hline Postal questionnaire & 30 & 52,6 \\
\hline Telephone-interview questionnaire & 5 & 8,8 \\
\hline Internet-questionnaire & 1 & 1,8 \\
\hline In-depth interview & 13 & 22,8 \\
\hline Focus-group & 2 & 3,5 \\
\hline $\begin{array}{l}\text { Combined (e.g. } \\
\text { pedom./accelerom./quest.) }\end{array}$ & 6 & 10,5 \\
\hline Sum & 57 & 100,0 \\
\hline \multicolumn{3}{|l|}{ Publication year } \\
\hline $2000-2009$ & 44 & 77,1 \\
\hline 1990 - 1999 & 12 & 21,1 \\
\hline $1980-1989$ & 1 & 1,8 \\
\hline Sum & 57 & 100,0 \\
\hline
\end{tabular}

described were cross-over activities (more than one activity).

\section{RESULTS}

Initial search results

Table 1 provides an overview of the review process. After completing the literature search, 4,189 articles were identified. The first-level review involved 460 articles related to physical activity and exercise. A second-level review was conducted in order to identify studies that were strictly physical activity/exercise and disability related. Among the 460 citations, 262 additional studies were excluded because they focused on specific rehabilitation 
interventions (e.g., gait training, functional electrical stimulation, constraint-induced movement training), athletes, elderly, lower back pain or fibromyalgia, and 131 studies were excluded because they were; testing a theoretical model or construct, describing the research field, literature reviews or commentaries. Another 10 studies were excluded because they did not primarily focus on physical activity. As a result, a total of 57 studies met the inclusion criteria and were included in the final analysis.

Physical activity studies sorted by disability, research design and publication year

Table 2 provides the characteristics of the 57 studies by disability, research design, data collection method, and publication year. Please note the high number of studies including people with spinal cord injury (SCI). We also noticed a significant number of studies including multiple sclerosis (MS). However, most of the studies included several diagnostic groups $(n=29,50.8 \%)$. Of the articles included, there was only one study from the eighties, and a small amount of studies from the nineties $(\mathrm{n}=12,21.1 \%$ ). Forty-two of the studies were cross-sectional and 15 were qualitative studies/case studies. About half of the studies in the present review used postal questionnaires as the main data collection method (see Table 2).

How active are adults with a physical disability?

In this review, studies that are measuring both total physical activity and leisure time physical activity are included. Several studies have reported activity levels, but only a few of them are accurate when it comes to description of the activity level. Among the diagnostic cross-over studies, Ellis et al. (2007) reported that among 223 adults $\left(M \_a g e=45.4\right.$ years, $\left.\mathrm{SD}=10.8\right)$ who completed a web-based survey, the average total physical activity score was 20.5 metabolic equivalent (METS)-hours/day ( $S D$ $=16.8$ ). This corresponds approximately to five hours a week with extensive walking or fast wheeling (IPAQ Research Committee, 2005).

Further, Santaigo \& Coyle (2004) reported leisure time physical activity participation to be 2.9 times $( \pm 5.12)$ per week in 170 women with physical disabilities, with $39.4 \%$ reporting no participation at all. In a study among Afro-American woman with physical disabilities $(N=50)$ Rimmer, Rubin, Braddock, \& Hedman (1999) revealed low levels of leisure time physical activity. Only $8.2 \%$ of the sample participated in leisuretime physical activity, and only $10 \%$ engaged in some kind of aerobic exercise three or more days per week for at least $15 \mathrm{~min}$. Unstructured physical activity (e.g., workrelated activity, housework, gardening, shopping) was nearly absent.

In a study among 4,038 adults with disability, Boslaugh and Andresen (2006) concluded that the majority of adults with disability did not meet basic recommendations for physical activity. The recommendation of the CDC and ACSM for moderate physical activity was used: moderate exercise for at least 30 minutes on 5 or more days per week in segments of at least 10 minutes each was considered to be sufficiently active. Participants were classified dichotomously as meeting this recommendation or not.

Among the studies on cerebral palsy (CP), van der Slot et al. (2007) concluded that the levels of everyday physical activity and community participation, measured by an activity monitor in adults with $\mathrm{CP}$, were comparable to levels in able-bodied. Other studies including persons with $\mathrm{CP}$ have reported quite low levels of activity. Jahnsen et al. (2003) reported that among 403 adults with CP, $46 \%$ were regularly physically active, defined as a minimum of 1 hour a week. In their qualitative study among 22 individuals aged 35-68 years, Sandstrom, Samuelsson and Oberg (2009) demonstrated a low activity level among the interviewed participants.

Several studies included persons with SCI. In a group of 985 persons with SCI, just over half $(52.1 \%, n=501)$ of participants 
engaged in no sports activities each week (Tasiemski, Kennedy, Gardner, \& Blaikley, 2004). They had no measure for total physical activity. Van den Berg-Emons et al. (2008) reported low activity level compared to ablebodied in a group $(N=16)$ of persons with SCI, one year after in-patient rehabilitation. The activity level was measured by activity- monitor. They calculated that the duration of average dynamic activities was 49 minutes per day in the SCI-group. This was significantly lower than the mean duration of dynamic activities among able-bodied (143 min. per day).

Table 3. Correlates of physical activity in adults with disabilities

Determinant or correlate

Associations with overall physical activity

\begin{tabular}{lc}
\hline Functioning and disability & -- \\
Increasing MS & -- \\
High degree of CP & -- \\
High level of SCI & - \\
High Body mass index & -- \\
Fatigue & -- \\
Environmental factors & - \\
High costs & - \\
Lack of transportation & - \\
Lack of assistance & -- \\
Lack of equipment & -- \\
Low accessibility & ++ \\
Lack of information & \\
Strong social support & - \\
Personal factors & - \\
Increasing age & 0 \\
Gender & - \\
Unemployment & -- \\
Depression & + \\
High intrinsic motivation & ++ \\
Self efficacy &
\end{tabular}

Note:

$++=$ repeatedly documented positive association with physical activity, $+=$ weak or mixed evidence of positive association with physical activity, $0=$ weak or mixed evidence of no association with physical activity, - = weak or mixed evidence of negative association with physical activity, - - = repeatedly documented negative association with physical activity. "Support" is defined as a code of - , - - , + and ++. Demographic and biological variables are not included in this summary. Adapted from Bauman, Sallis, Dzewaltowski and Owen (2002).

Does the disability and the level of functioning count?

Table 3 provides an overview of correlates of physical activity and disability. Several studies have outlined functioning and disability as an important correlate when discussing physical activity and disability. In the following we have reported some of these studies, starting with the cross-over studies without any specific diagnosis. 
Longmuir and Bar-Or (2000) observed significant differences in habitual physical activity between disability types, specific diagnostic categories, and age in a study among 957 youths with a disability. They also found significant differences in perceived participation limitations among disability types. Youths with $\mathrm{CP}$, muscular dystrophy, and visual impairment had the most sedentary lifestyles. Gender, however, did not influence the results. Among a number of variables, Santiago \& Coyle (2004) emphasized that deconditioning was inversely related to the ability of 170 moderately mobility- impaired women to participate in leisure time physical activity. Shifflett, Cator, \& Megginson (1994) also reported that functional health barriers in 62 persons with a disability had a negative impact on their adherence to an active lifestyle.

Twenty percent of the survey respondents in a study $(N=2298)$ by Finch, Owen, \& Price (2001) posted current injury or disability as a reason for not being more active. There was a significant trend toward more frequently mentioning current injury or disability as a barrier for participation in activities with increased age. High body mass index and current low physical activity levels were significantly related to the injury or disability barriers. This was supported by Warms et al (2007) and Ellis et al. (2007). Further, adults with disabilities $(N=117)$ were more likely to engage in a healthpromoting lifestyle if less mechanical assistance was required (Stuifbergen \& Becker, 1994), assuming that less mechanical assistance also indicates higher physical functioning. In a study by Bodde, Seo and Frey (2009), a national US-sample of 46,883 adults with disabilities was examined. They reported that physical activity participation was significantly associated with self-rated health status.

When looking at the diagnose-specific studies, Manns \& Chad (1999) found that among 38 participants with SCI, physical activity was negatively correlated with reduced physical functioning in quadriplegic and paraplegic persons. Hence, higher scores for physical independence, mobility, and occupation were positively correlated with physical activity in quadriplegic persons. They also concluded that physical activity may play an important role in perceived physical function for persons with SCI, and particularly for persons with quadriplegic injuries.

Furthermore, studies conducted in the domain of multiple sclerosis (MS) also give support to level of functioning as an important correlate. Becker and Stuifbergen (2004) reported that fatigue and grade of impairment were significantly associated with decreased activity level in a study in 2,710 persons with MS. This observation was supported by several studies which found that increased MS and decreased function reduced the activity level (Crocker, 1993; Kasser, 2009; Motl, Snook, McAuley, Scott, \& Gliottoni, 2007; Stroud, Minahan, \& Sabapathy, 2009).

Finally, CP represents a heterogeneous disability group. Not surprisingly, studies have revealed associations between physical activity and type of disability and functional level. According to Jahnsen et al.(2003), the degree of CP seems to play a main role for the activity level. This was supported by van Eck et al. (2008), who found low activity levels in persons with more severe CP (Gross Motor Function Classification System - GMFCS III/IV) than persons with GMFCS I/II.

In summary, increasing body mass index, low levels of health status, low mobility level, and low physical function seems to be correlated with reduced activity level. Further, increasing severity of MS, and severe degree of SCI or CP also demonstrate high correlation with reduced activity level.

\section{Environmental factors}

Focus on environmental barriers and facilitators have increased in this field over the last decade. These factors are many and quite heterogeneous, because we are discussing different kind of environments (e,g., social, natural, technical, equipment, built environment, facilities, transportation etc). Among the general studies, Lockwood (1997) explored views and behaviors of 493 
people with and without disabilities in relation to their levels of participation in physical activity in settings ranging from segregated to fully inclusive. The findings identified that there is considerable room for improvement in areas such as training, flexible programming, support services for inclusive settings and transport to sporting facilities.

The four major environmental barriers reported by Rimmer et al. (2000) among fifty African American women with physical disabilities were cost of the exercise program $(84.2 \%)$, transportation $(60.5 \%)$, and not knowing where to exercise $(57.9 \%)$. Financial resources were also representing important barriers to physical activity in the studies by Becker and Stuifbergen (2004) and Scelza et al. (2005). The latter study also emphasized the importance of knowledge of where to exercise and access to a place to exercise among 72 individuals with SCI. Ellis et al. (2007) revealed that factors obstructing physical activity were disability itself and associated symptoms, and a lack of access to adequate facilities, equipment, or programs. The factors that facilitate physical activity were access to adequate facilities, equipment, or programs, and support or assistance.

Rimmer et al. (2008) administered a survey to a group of 83 adults with unilateral stroke ( $M$ age $=54.2$ years $)$ to explore their perceived barriers to exercise. The five most common barriers ranked in order were (1) cost of the program (61\%), (2) lack of awareness of a fitness centre in the area $(57 \%)$, (3) no means of transportation to a fitness centre $(57 \%)$, (4) no knowledge of how to exercise (46\%), and (5) no knowledge of where to exercise (44\%). As revealed, the financial cost has repeatedly been emphasized in several studies as a barriers to participate in physical activity (Becker \& Stuifbergen, 2004; Scelza, Kalpakjian, Zemper, \& Tate, 2005; Rimmer et al., 2008; Rimmer et al., 2000)

Shifflett, Cator and Megginson (1994) also pointed out access to activities and facilities as correlates of leisure time physical activity level in their study, while findings among 206 persons with SCI suggested a role of the physical environment in predicting physical activity; particularly moderate intensity leisure time wheeling (Arbour \& Martin Ginis, 2007). In a qualitative interview-study with 32 participants, Vissers et al. (2008) discussed the most important barriers to and facilitators of the level of everyday physical activity in thirty-two persons with a SCI. The major environmental barriers were accessibility of stores and buildings. The most frequently mentioned facilitators were preparation in the rehabilitation centre with respect to daily activities and social activities and stimulation to be physically active.

When caregivers perceived greater benefits of exercise, adults with CP $(N=83)$ were likely to exercise more frequently (Heller, Ying, Rimmer, \& Marks, 2002). This is supported by Sandstrom, Samuelsson and Oberg, who committed an interview with 22 community-living adults (35 - 68 years) with CP. They identified five different themes, and among the environmental factors we mention "being integrated in daily life", and "supportive healthcare with competent professionals" from that study. Social support was also underlined as important mediator on the pathway between physical activity and quality of life in a sample of persons with MS (Motl \& McAuley, 2009).

Among wheelchair users, Warms et al. (2007), demonstrated that subjectively measured activity correlated significantly with healthcare providers discussing exercise, and social support for exercise. These results also adhere to the results of Standal and Jespersen (2008) who investigated the learning that took place when people with disabilities interacted in a rehabilitation context. The results indicated that peer learning extends beyond skills and techniques, and includes ways for the participants to make sense of their situations as wheelchair users.

Rolfe, Yoshida, Renwick and Bailey (2009) explored how material and social structures and functions, existing and operating within 15 disabled women's 
communities at community-based exercise facilities, affected their participation. They concluded that the first and most important step in encouraging and facilitating women's exercise participation was to engage women living with disabilities in dialogue about their needs and preferences, and to include them in the planning and development of accessible exercise programs and community services. When support (instrumental, emotional, informational) was provided to participants, each of these had a positive influence on physical activity participation in a qualitative study among seven participants with Parkinson's disease (Ravenek \& Schneider, 2009).

The trend in the literature revealed that costs, physical access, equipment, assistance and social support were the strongest environmental correlates to physical activity for persons with a disability.

\section{Personal factors}

Among the personal factors, increasing age seemed to be associated with reduced activity level (Boslaugh \& Andresen, 2006; Finch, Owen, \& Price, 2001; Motl, Snook, McAuley, Scott, \& Hinkle, 2007; Warms, Belza, \& Whitney, 2007). However, increasing age may also indicate reduced level of physical function. Female gender was associated with a lower level of physical activity, but this does not correspond with Boslaugh and Andresen (2006) who found no correlation between gender and activity level. In the same study, African Americans were significantly less active and annual income of $\$ 50,000$ or higher were significantly related to higher physical activity level.

Santiago and Coyle (2004) found that secondary conditions of isolation were significantly and inversely related to leisure time physical activity participation, while Mitra, Wilber, Allen and Walker (2005) found that depression was negatively correlated with physical exercise. Consequently, reduced mental health and depression seems to interfere with physical activity among adults with a disability. In a qualitative interview-study by Goodwin and
Staples (2005), nine youth campers with physical, sensory, or behavioral disabilities experienced increased self-reliance, independence, and new understandings of their physical potential after participating in activities at a summer camp.

Among the diagnose specific studies, Becker and Stuifbergen (2004) reported that intrapersonal factors contributed significantly to the prediction of barriers to healthy behavior in persons with MS $(N=2710)$, and Jahnsen et al. (2003) found that having learnt to take responsibility for personal health during childhood was the strongest correlate for being physically active as an adult with CP $(N=406)$ of persons with CP.

The aim of the study by Wahman, Biguet and Levi (2006) was to identify factors that may promote participation in physical activity among people with SCI. In qualitative multiple case studies, sixteen participants with SCI were interviewed. The main themes they identified were: using cognitive and behavioural strategies; exploring motivation post injury; and capturing new frames of reference. Further, in another study, the most frequently cited concerns about barriers among individuals with SCI were lack of motivation, lack of energy and lack of interest (Scelza et al., 2005). Tasiemski et al. (2004) detected that persons with SCI $(N=678)$ had lower levels of athletic identity than ablebodied adults and adolescents with physical disabilities. Finally, Lannem, Sorensen, Froslie and Hjeltnes (2009) concluded that participants $(N=69)$ in a study with incomplete SCI who exercised regularly experienced a significantly higher life satisfaction and perceived exercise fitness, but lower perceived exercise mastery than their inactive peers.

Motl and McAuley (2009) and Motl, McAuley, Snook and Gliottoni (2009) observed a pattern of relationships that supported the possibility that physical activity is indirectly associated with improved quality of life through pathways that include fatigue, pain, social support, and self-efficacy in individuals with MS. Their results were supported in a study among 786 persons with 
MS. The effects of severity of illness on quality of life were mediated partially by health-promoting behaviors, resources, barriers, self-efficacy and acceptance (Stuifbergen, Seraphine, \& Roberts, 2000).

Self-efficacy correlated significantly with vigor for the fifty wheelchair tennis participants in a study by Greenwood \& Dzewaltowski (1990). Furthermore, wheelchair-mobility self-efficacy correlated significantly with mood factors except depression for the wheelchair non-tennis participants. It was concluded that wheelchair mobile individuals participating in tennis may be more confident about performing tennis skills and general wheelchair mobility tasks than are wheelchair mobile nonparticipants. Several studies have revealed that a high score on self-efficacy for exercise is a significant correlate of physical activity (Kasser, 2009; Kinne et al., 1999; Motl, McAuley, Snook, \& Gliottoni, 2009; Motl \& McAuley, 2009; Plow, Resnik, \& Allen, 2009; Stroud et al., 2009; Stuifbergen \& Becker, 1994), but it is also interesting to notice that five of these six studies have been conducted in a sample of persons with MS.

In conclusion, several personal factors seem to interplay with physical activity. Increasing age, unemployment and depression is correlated with reduced physical activity, while high intrinsic motivation, coping skills and exercise efficacy are correlates of increasing physical activity.

\section{DISCUSSION}

Traditionally, personal factors as correlates of physical activity among people with a disability have received little attention, but there are an increasing number of studies that addresses this issue. The results demonstrate no strong evidence for gender as a strong correlate. This is not in line with research among able-bodied, where male gender is positively correlated with higher amount of intensity and total physical activity (Anderssen \& Strømme, 2001).

Very few studies have investigated motivational issues (Kinne et al., 1999; Scelza et al., 2005). However, there are different approaches to motivation, and while enjoyment (Sandstrom, Samuelsson, \& Oberg, 2009) is representing intrinsic motivation, awareness of the health-benefits of physical activity (Stroud et al., 2009) is representing a controlled motivationregulation. Health professionals often assume that persons with a disability are motivated by the health imperatives because of their disability, but additional research is needed to increase our knowledge about these issues. What energizes physical activity behavior seems to be a central question, for persons with a disability, as well as for able-bodied.

Clearly, mental health and depression seems to interplay with physical activity (Mitra, Wilber, Allen, \& Walker, 2005; Santiago \& Coyle, 2004). This corresponds with earlier results (Stewart et al., 1994). The incidence of depression is higher among people with a disability (Roe, Dalen, Lein, \& Bautz-Holter, 2008) than in the able-bodied population, and may to some extent explain a part of the reduced activity level in a population with a disability.

Among the frequently represented environmental factors we detected that the costs of the activity played a major role. The financial resources in this population may be limited, and results in reduced activity level (Becker \& Stuifbergen, 2004; Scelza et al., 2005; Rimmer et al., 2008; Rimmer et al., 2000). Many individuals with a disability are living on social security, and additionally, their participation most often requires adapted facilities, equipment and personal support for being physically active. It is likely that limited income and need for additional paid services to be physically active results in an even more challenging situation, which might lead to reduced physical activity as compared to an able-bodied population.

Further, there seems to be a connection between transportation to facilities, access to facilities, adapted equipment and physical activity. Not surprisingly, the strongest evidence for these limitations are found in studies representing persons with severe mobility impairments like SCI (Scelza et al., 2005; Vissers et al., 2008) 
and MS (Plow et al., 2009). Hence, an inaccessible environment seem to be negatively correlated with physical activity in populations with SCI (Arbour \& Martin Ginis, 2007). As an example, lack of paved pathways is an obstacle for wheelchair access.

Focus on support and assistance is needed in some populations (eg. Lockwood, 1997), but were not among the strongest correlates in the studies reviewed. More emphasized was the need for information on where to exercise (Buffart, Westendorp, van den Berg-Emons, Stam, \& Roebroeck, 2009; Ravenek \& Schneider, 2009), indicating that there is a need for more research on how to reach the targeted population with information about adapted facilities, equipment and activity.

Social support for being physically active represents some of the strongest correlates, and are represented across diagnosis and age (Ellis et al., 2007; Motl et al., 2009; Plow et al., 2009; Standal \& Jespersen, 2008; Stuifbergen et al., 2000; Wahman, Biguet, \& Levi, 2006; Warms et al., 2007), including support from health professionals (Ellis et al., 2007). The solid documentation on this issue emphasizes the need for additional research on how to change attitudes among family, friends and peers. Activity planners should plan programs that place emphasis on modifying the social environment and removing attitudinal barriers.

The level of physical activity among adults with a disability demonstrated some differences between types and degrees of functioning and disability that could be expected, and indicated a positive correlation between reduced functioning and reduced physical activity. This seems to be most clear in the populations with severe activity limitations like MS (Becker \& Stuifbergen, 2004; Crocker, 1992; Motl et al., 2007; Stroud et al., 2009) CP (Jahnsen et al., 2003) and SCI (Manns \& Chad, 1999). These groups also struggle with fatigue and exertion, which seems to be negatively correlated with physical activity in this population (Becker \& Stuifbergen, 2004; Fernandez, Pitetti, \&
Betzen, 1990), and especially in MS (Motl et al., 2009; Motl \& McAuley, 2009). Daily activities require additional energy for those who are severely impaired (Kemp \& Thompson, 2002), and may have an influence on the activity level. However, the results also give some support to statements that there is a connection between general, heterogeneous groups with disability and increasing inactivity (Boslaugh \& Andresen, 2006), and that having a disability, regardless of type, reduces the average activity level. Research on the effect of body mass index on activity in this population is needed.

We can conclude that people with a disability are on average less active than the general population, but we must be aware of the great differences in defining physical activity and ways of measuring the activity (Cervantes \& Porretta, 2010). This makes it further difficult to compare results from various studies. However, using the acknowledged definition by Caspersen, Powell, \& Christenson (1985) is quite usual, and probably also correct, because many persons with a disability use much energy to finish daily activities. In a public health perspective, daily tasks and activities that require calorie expenditure are also important to measure. Low levels of physical activity are defined as less than half an hour, five days a week ( $2 \frac{1}{2}$ hours per week) with moderate physical activity (Haskell et al., 2007).

Most of the studies are across diagnoses, probably because of the limited number of people within the different categories or diagnosis. It is challenging to get access to a representative sample, especially for low-incidence disability groups (Rimmer et al., 2010). However, it need to be addressed that SCI also represents a lowincidence disability group, but is frequently represented here. Unfortunately, there is a lack of research including persons with hearing disabilities and persons with visual impairment, which represent high-incidence disability groups. Accordingly, the number of incidents does not explain the whole picture, so there is a need for other ways to explain the different representation of disability 
groups. Another possible explanation may be connected to the fact that the studies presented here in this review on MS and SCI represent a few but active research environments. This may indicate that scientific environment and the choice of topics, as well as economical issues and grants may play a role of the priority in this field.

Persons with stroke are only represented in one study in this review. This reflects the age criterion set for ages 16-65 years. The incidence of stroke is much higher after 65 years, and can probably explain why only one study is present here. The same explanation may be given for Parkinson's disease, which is quite often represented in studies on persons with disabilities, but the incidence of Parkinson's is low under 65 years.

\section{Study limitations}

The search terms we used may not have captured all the relevant studies, or the number and scope of search-engines could be too limited. There is also a possibility that the exclusion criteria selected were too many, or too narrow. In addition, the review was limited to papers published in English with abstract and only peer-reviewed journals. As such, unpublished papers from proceedings and abstracts were excluded due to convenience. Studies involving adults older than 65 years were not reported, which limits the findings of age-related conditions like Parkinson's disease and stroke. We also excluded research from education, but are aware of the extensive research and the significant contribution coming from this research field.

\section{Future research}

The 57 studies identified in this review were spread across seven different disability groups (including one category that combined two or more types of disabilities) although heterogeneous populations make it easier to recruit subjects (e.g., including individuals with paraplegia and quadriplegia in the same study) and obtain higher levels of statistical power, it limits the generalizability of the results. Whenever possible, studies should be designed with more homogeneous samples in terms of age, health status, and functional level. Consequently, we emphasize the need for researchers that address specific disability groups, but are also aware of the heterogeneity between and within disability groups. The low incidence of many disabilities make it extremely difficult to obtain adequate sample sizes when recruiting subjects from one setting (Rimmer et al., 2010).

It is difficult to make comparisons between studies when instruments are not the same or not explained well enough to make critical comparisons between them. Cervantes and Porretta (2010) suggest the use of a combination of measurement methods (i.e., multiple measures of physical activity), and we agree that this appears to offer the best solution for assessing the level of physical activity. However, until then, we may suggest the development and consensus in the future to use of one survey to measure physical activity among persons with a disability.

Most research material is conducted with volunteers, and it is difficult to generalize the findings of the study to the entire subgroup. In general, those who are responding are also those most interested in physical activity. The people who volunteer for exercise- related research may also have a higher functional level. Given the complexity of identifying and recruiting individuals with disabilities for exercise research, classifying subjects by function (ICF) rather than disability may be an alternative approach to increase recruitment size and identify key health outcomes that generalize across disability groups (Rimmer et al., 2010).

Perspective

There is a need to establish a stronger evidence base to increase our knowledge of correlates, determinants and associations in relation to physical activity and disability. The results revealed a need for common measurement methods to assess physical activity among persons with a disability. This is in line with previous research (Cervantes \& 
Porretta, 2010). Further, there is a need for research on determinants and associations in relation to physical activity and disability among specific diagnosis, and specifically among low incidence groups. Among the environmental factors, we emphasize the need for research on informational routines and how to reach the targeted populations. The impact of gender among people with a disability seems to be an understudied issue in physical activity and disability research. Finally, in order to understand engagement and participation in physical activity among people with a disability, we must increase our knowledge about motivational processes, selfregulation models and coping strategies, emphasizing the need for additional research with a broader theoretical approach to identify different aspects of physical activity behavior.

\section{REFERENCES}

Anderssen, S. A. \& Strømme, S. B. (2001). Physical activity and health recommendations. Tidsskriftet for den Norske Lageforening, 121, 2037-41.

Arbour, K. P. \& Martin Ginis, K. A. (2007). Does the environment matter? Exploring the role of the physical environment in predicting leisure-time wheeling among people with spinal cord injury. Journal of Sport \& Exercise Psychology, 29, S144S145.

Bauman, A. E., Sallis, J. F., Dzewaltowski, D. A., \& Owen, N. (2002). Toward a Better Understanding of the Influences on Physical Activity The Role of Determinants, Correlates, Causal Variables, Mediators, Moderators, and Confounders. American Journal of Preventive Medicine, 23, 5-14.

Becker, H. \& Stuifbergen, A. (2004). What makes it so hard? Barriers to health promotion experienced by people with multiple sclerosis and polio. Family \& Community Health, 27, 75-85.

Bodde, A. E., Seo, D. C., \& Frey, G. (2009). Correlation between physical activity and self-rated health status of non-elderly adults with disabilities. Preventive Medicine, 49, 511-514.
Boslaugh, S. E. \& Andresen, E. M. (2006). Correlates of physical activity for adults with disability. Preventing Chronic Disease, 3, A78.

Buffart, L. M., Westendorp, T., van den BergEmons, R. J., Stam, H. J., \& Roebroeck, M. E. (2009). Perceived barriers to and facilitators of physical activity in young adults with childhood-onset physical disabilities. Journal of Rehabilitation Medicine, 41, 881-885.

Caspersen, C. J., Powell, K. E., \& Christenson, G. M. (1985). PhysicalActivity, Exercise, and Physical-Fitness Definitions and Distinctions for HealthRelated Research. Public Health Reports, 100, 126-131.

Centers for Disease Control and Prevention (2007). Physical activity among adults with a disability - United States, 2005 (Rep. No. 56).

Cervantes, C. M. \& Porretta, D. L. (2010). Physical Activity Measurement Among Individuals With Disabilities: A Literature Review. Adapted Physical Activity Quarterly, 27, 173-190.

Compton, D. M., Eisenman, P. A., \& Henderson, H. L. (1989). Exercise and fitness for persons with disabilities. Sports Medicine, 7, 150-162.

Crocker, P. R. E. (1992). Perceived challenge in physical activity by individuals with physical disabilities: the relationship between appraisal and affect. Adapted Physical Activity Quarterly, 9, 130-140.

Crocker, P. R. E. (1993). Sport and Exercise Psychology and Research With Individuals With Physical Disabilities: Using Theory to Advance Knowledge. Adapted Physical Activity Quarterly, 10, 324-335.

Ellis, R., Kosma, M., Cardinal, B. J., Bauer, J. J., \& McCubbin, J. A. (2007). Physical activity beliefs and behaviour of adults with physical disabilities. Disability and Rehabilitation, 29, 1221-1227.

Fernandez, J. E., Pitetti, K. H., \& Betzen, M. T. (1990). Physiological capacities of individuals with cerebral palsy. Human Factors: The Journal of the Human Factors and Ergonomics Society, 32, 457-466. 
Finch, C., Owen, N., \& Price, R. (2001). Current injury or disability as a barrier to being more physically active. Medicine and Science in Sports and Exercise, 33, 778782.

Goodwin, D. L. \& Staples, K. (2005). The Meaning of Summer Camp Experiences to Youths With Disabilities. Adapted Physical Activity Quarterly, 22, 159-177.

Greenwood, C. M. \& Dzewaltowski, D. A. (1990). Self-efficacy and psychological well-being of wheelchair tennis participants and wheelchair nontennis participants. Adapted Physical Activity Quarterly, 7, 1221.

Haskell, W. L., Lee, I. M., Pate, R. R., Powell, K. E., Blair, S. N., Franklin, B. A. et al. (2007). Physical activity and public health - Updated recommendation for adults from the American college of sports medicine and the American heart association. Circulation, 116, 1081-1093.

Heath, G. W. \& Fentem, P. H. (1997). Physical activity among persons with disabilities - a public health perspective. Exercise Sport Science Review, 25, 195234.

Heller, T., Ying, G. S., Rimmer, J. H., \& Marks, B. A. (2002). Determinants of exercise in adults with cerebral palsy. Public Health Nursing, 19, 223-231.

Hempel, S., Norman, G., Golder, S., AguiarIbanez, R., \& Eastwood, A. (2008). Psychosocial interventions for nonprofessional carers of people with Parkinson's disease: a systematic scoping review. Journal of Advanced Nursing, 64, 214-228.

IPAQ Research Committee (2005). Guidelines for Data Processing and Analysis of the International Physical Activity Questionnaire (IPAQ). [On-line]. Available: www.ipaq.ki.se

Jahnsen, R., Villien, L., Aamodt, G., Stanghelle, J. K., \& Holm, I. (2003). Physioteray and Physical Activity Experiences of Adult with Cerebral Palsy, with Implications for Children. Advances in Physioterapy, 5, 21-32.
Kasser, S. (2009). Exercising with multiple sclerosis: insights into meaning and motivation. Adapted Physical Activity Quarterly, 26, 274-289.

Kemp, B. J. \& Thompson, L. (2002). Ageing and spinal cord injury: medical, functional and psychological changes. Spinal Cord Injury Nursing, 19, 51-60.

Kinne, S., Patrick, D. L., \& Maher, E. J. (1999). Correlates of exercise maintenance among people with mobility impairments. Disability and Rehabilitation, 21, 15-22.

Lannem, A. M., Sorensen, M., Froslie, K. F., \& Hjeltnes, N. (2009). Incomplete spinal cord injury, exercise and life satisfaction. Spinal Cord, 47, 295-300.

Lockwood, R. (1997). Physical activity for people with disabilities : participation, satisfaction and barriers. ACHPER Healthy Lifestyles Journal, 44, 21-25.

Longmuir, P. E. \& Bar-Or, O. (2000). Factors Influencing the Physical Activity Levels of Youths With Physical and Sensory Disabilities. Adapted Physical Activity Quarterly, 17, 40-53.

Manns, P. J. \& Chad, K. E. (1999). Determining the relation between quality of life, handicap, fitness, and physical activity for persons with spinal cord injury. Archives of Physical Medicine and Rehabilitation, 80, 1566-1571.

McGuire, L. C., Strine, T. W., Okoro, C. A., Ahluwalia, I. B., \& Ford, E. S. (2007). Healthy lifestyle behaviors among older U.S. adults with and without disabilities, Behavioral Risk Factor Surveillance System, 2003. Preventing Chronic Disease, 4, A09.

Mitra, M., Wilber, N., Allen, D., \& Walker, D. K. (2005). Prevalence and correlates of depression as a secondary condition among adults with disabilities. American Journal of Orthopsychiatry, 75, 76-85.

Motl, R. W. \& McAuley, E. (2009). Pathways between physical activity and quality of life in adults with multiple sclerosis. Health Psychology, 682-689.

Motl, R. W., McAuley, E., Snook, E. M., \& Gliottoni, R. C. (2009). Physical activity and quality of life in multiple sclerosis: 
Intermediary roles of disability, fatigue, mood, pain, self-efficacy and social support. Psychology Health \& Medicine, 14, 111124.

Motl, R. W., Snook, EM., McAuley, E., Scott, J. A., \& Gliottoni, R. C. (2007). Are physical activity and symptoms correlates of functional limitations and disability in multiple sclerosis? Rehabilitation Psychology, 463-469.

Motl, R. W., Snook, EM., McAuley, E., Scott, J. A., \& Hinkle, M. L. (2007). Demographic correlates of physical activity in individuals with multiple sclerosis. Disability \& Rehabilitation, 29, 1301-1304.

Pate, R. R., Pratt, M., Blair, S. N., Haskell, W. L., Macera, C. A., Bouchard, C. et al. (1995). Physical-Activity and Public-Health - A Recommendation from the Centers-ForDisease-Control-And-Prevention and the American-College-Of-Sports-Medicine.

Jama-Journal of the American Medical Association, 273, 402-407.

Petticrew, M. \& Roberts, H. (2006). Systematic Reviews in the Social Sciences: A Practical Guide. Malden, MA: Blackwell Publishing Company.

Physical Activity Guidelines Advisory Committee (2008). Physical Activity Guidelines Advisory Committee Report Washington, DC: U.S: Department of Health and Human Services.

Plow, M. A., Resnik, L., \& Allen, S. M. (2009). Exploring physical activity behaviour of persons with multiple sclerosis: a qualitative pilot study. Disability \& Rehabilitation, 31, 1652-1665.

Ravenek, M. J. \& Schneider, M. A. (2009). Social support for physical activity and perceptions of control in early Parkinson's disease. Disabil.Rehabil., 31, 1925-1936.

Rimmer, J. H. (2005). The Conspicuous Absence of People With Disabilities in Public Fitness and Recreation Facilities: Lack of Interest or Lack of Access? American Journal of Health Promotion, 19, 327-329.

Rimmer, J. H. (2006). Use of the ICF in identifying factors that impact participation in physical activity/rehabilitation among people with disabilities. Disability \& Rehabilitation, 28, 1087-1095.

Rimmer, J. H., Braddock, D., \& Pitetti, K. H. (1996). Research on physical activity and disability: An emerging national priority. Medicine and Science in Sports and Exercise, 28, 1366-1372.

Rimmer, J. H., Chen, M. D., McCubbin, J. A., Drum, C., \& Peterson, J. (2010). Exercise Intervention Research on Persons with Disabilities What We Know and Where We Need to Go. American Journal of Physical Medicine \& Rehabilitation, 89, 249-263.

Rimmer, J. H., Rubin, S. S., \& Braddock, D. (2000). Barriers to exercise in African American women with physical disabilities. Archives of Physical Medicine and Rehabilitation, 81, 182-188.

Rimmer, J. H., Rubin, S. S., Braddock, D., \& Hedman, G. (1999). Physical activity patterns of African-American women with physical disabilities. Medicine \& Science in Sports \& Exercise, 31, 613-618.

Rimmer, J. H., Wang, E., \& Smith, D. (2008). Barriers associated with exercise and community access for individuals with stroke. Journal of Rehabilitation Research and Development, 45, 315-322.

Roe, C., Dalen, H., Lein, M., \& Bautz-Holter, E. (2008). Comprehensive rehabilitation at Beitostolen Healthsports Centre: Influence on mental and physical functioning. Journal of Rehabilitation Medicine, 40, 410-417.

Rolfe, D. E., Yoshida, K., Renwick, R., \& Bailey, C. (2009). Negotiating participation: how women living with disabilities address barriers to exercise. Health Care for Women International, 30, 743-766.

Sandstrom, K., Samuelsson, K., \& Oberg, B. (2009). Prerequisites for carrying out physiotherapy and physical activity experiences from adults with cerebral palsy. Disability \& Rehabilitation, 31, 161-169.

Santiago, M. C. \& Coyle, C. P. (2004). Leisure-time physical activity and secondary conditions in women with physical disabilities. Disability \& Rehabilitation, 26, 485-494.

Scelza, W. M., Kalpakjian, C. Z., Zemper, E. D., \& Tate, D. G. (2005). Perceived barriers 
to exercise in people with spinal cord injury. American Journal of Physical Medicine \& Rehabilitation, 84, 576-583.

Shifflett, B., Cator, C., \& Megginson, N. (1994). Active lifestyle adherence among individuals with and without disabilities. Adapted Physical Activity Quarterly, 11, 359-367.

Standal, O. F. \& Jespersen, E. (2008). Peers as resources for learning: A situated learning approach to adapted physical activity in rehabilitation. Adapted Physical Activity Quarterly, 25, 208-227.

Standal, O. F. \& Jespersen, E. (2008). Peers as resources for learning: A situated learning approach to adapted physical activity in rehabilitation. Adapted Physical Activity Quarterly, 25, 208-227.

Stewart, A. L., Hays, R. D., Wells, K. B., Rogers, W. H., Spritzer, K. L., \& Greenfield, S. (1994). Long-Term Functioning and Well-Being Outcomes Associated with Physical-Activity and Exercise in Patients with Chronic Conditions in the Medical Outcomes Study. Journal of Clinical Epidemiology, 47, 719730.

Stroud, N., Minahan, C., \& Sabapathy, S. (2009). The perceived benefits and barriers to exercise participation in persons with multiple sclerosis. Disability \& Rehabilitation, 31, 2216-2222.

Stuifbergen, A. K. \& Becker, H. A. (1994). Predictors of Health-Promoting Life-Styles in Persons with Disabilities. Research in Nursing \& Health, 17, 3-13.

Stuifbergen, A. K., Seraphine, A., \& Roberts, G. (2000). An explanatory model of health promotion and quality of life in chronic disabling conditions. Nursing Research, 49, 122-129.

Tasiemski, T., Kennedy, P., Gardner, B. P., \& Blaikley, R. A. (2004). Athletic Identity and Sports Participation in People With Spinal Cord Injury. Adapted Physical Activity Quarterly, 21, 364-378.

Taylor, W. C., Baranowski, T., \& Young, D. R. (1998). Physical activity interventions in low-income, ethnic minority, and populations with disability. American
Journal of Preventive Medicine, 15, 334343.

Trost, S. G., Owen, N., Bauman, A. E., Sallis, J. F., \& Brown, W. (2002). Correlates of adults' participation in physical activity: review and update. Medicine \& Science in Sports \& Exercise, 34, 1996-2001.

van den Berg-Emons, R. J., Bussmann, J. B., Haisma, J. A., Sluis, T. A., van der Woude, L. H., Bergen, M. P. et al. (2008). A prospective study on physical activity levels after spinal cord injury during inpatient rehabilitation and the year after discharge. Archives of Physical Medicine and Rehabilitation, 89, 2094-2101.

van der Ploeg, H. P., van der Beek, A. J., van der Woude, L. H. V., \& van Mechelen, W. (2004). Physical activity for people with a disability - A conceptual model. Sports Medicine, 34, 639-649.

van der Slot, W. M. A., Roebroeck, M. E., Landkroon, A. P., Terburg, M., van den Berg-Emons, R., \& Stam, H. J. (2007). Everyday physical activity and community participation of adults with hemiplegic Cerebral Palsy. Disability \& Rehabilitation, 29, 179-189.

van Eck, M., Dallmeijer, A. J., Beckerman, H., van den Hoven, P. A. M., Voorman, J. M., \& Becher, J. G. (2008). Physical Activity Level and Related Factors in Adolescents With Cerebral Palsy. Pediatric Exercise Science, 20, 95-106.

Vissers, M., Berg-Emons, R., Sluis, T., Bergen, M., Stam, H., \& Bussmann, H. (2008). Barriers to and facilitators of everyday physical activity in persons with a spinal cord injury after discharge from the rehabilitation centre. Journal of Rehabilitation Medicine, 40, 461-467.

Wahman, K., Biguet, G., \& Levi, R. (2006). What promotes physical activity after spinal cord injury? An interview study from a patient perspective. Disability \& Rehabilitation, 28, 481-488.

Warms, C. A., Belza, B. L., \& Whitney, J. D. (2007). Correlates of physical activity in adults with mobility limitations. Family \& Community Health, 30, S5-16. 
Washburn, R. A., Zhu, W. M., McAuley, E., Frogley, M., \& Figoni, S. F. (2002). The physical activity scale for individuals with physical disabilities: Development and evaluation. Archives of Physical Medicine and Rehabilitation, 83, 193-200.
WHO (2001). World Health Organization: International Classification of Functioning, Disability and Health Geneva: ICF.

Corresponding author's e-mail address saebu@online.no

\title{
KÖRPERBEHINDERUNG UND BEWEGUNG: EIN LITERATURÜBERBLICK ÜBER DIESBEZÜGLICHE KORRELATIONEN UND ASSOZIATIONEN
}

(Abstract)

Die Absicht dieses Artikels war es, die Literatur, die sich mit den Korrelationen und Assoziationen zwischen körperlicher Aktivität Erwachsener (im Alter zwischen 16 und 65 Jahren) und Körperbehinderung beschäftigt, $\mathrm{zu}$ untersuchen. Es wurde elektronisch nach Forschungsartikeln gesucht, die zwischen 1989 und 2009 veröffentlicht worden waren. Es wurden dazu spezifische Einschlusskriterien identifiziert. Die Suche ergab 4.189 Artikel, wobei allerdings nur 57 alle spezifizierten Kriterien erfüllten. Sie repräsentierten sieben verschiedene Behinderungsgruppen, einschließlich einer Crossover-Kategorie mit zwei oder mehr Behinderungsformen. Die von der Weltgesundheitsorganisation (WHO) entwickelte Internationale Klassifikation der Funktionsfähigkeit, Behinderung und Gesundheit (ICF) wurde als Bezugssystem zur Strukturierung der Ergebnisse verwendet. Die Resultate deckten auf, dass es einen wesentlichen Kern an Forschung zu einigen wenigen Behinderungsgruppen gibt, wozu Rückenmarksverletzungen und Multiple Sklerose zählen. Signifikante Zusammenhänge konnten in Bezug auf die Form der Behinderung und die Funktionsfähigkeit gefunden werden, aber auch zwischen Umweltfaktoren (z.B. Kosten, Zugänglichkeit, bauliche Umwelt, Information und soziale Unterstützung) und personalen Faktoren (z.B. Alter, Trainingsselbstwirksamkeit, Depression, mentale Gesundheit). Die Diskussion der Untersuchungsergebnisse bezieht sich auf zukünftige Studien zu körperlicher Aktivität mit Menschen mit Behinderungen.

\section{SCHLÜSSELWÖRTER: körperliche Aktivität, Training, Behinderung, Zusammenhänge,} bestimmende Faktoren

\section{HANDICAP MOTEUR ET ACTIVITE PHYSIQUE : REVUE DE LITTÉRATURE SUR LES CORRELATS ET ASSOCIATIONS}

\author{
(Résumé)
}

L'objectif de cet article était d'établir une revue de la littérature sur les corrélats et les associations de l'activité physique et du handicap moteur chez des personnes adultes (16-65 ans). Une recherche électronique a été réalisée pour identifier les articles scientifiques publiés entre 1980 et 2009. Des critères de sélection spécifiques ont été choisis. La recherche a fourni au total 4189 articles ; cependant seulement 57 ont été retenus sur la base des critères de sélection. Ces articles représentaient 7 groupes de handicap différent, incluant une catégorie pour laquelle deux ou plusieurs handicaps étaient compris. La classification internationale du fonctionnement, du handicap et de la santé développée par l'Organisation Mondiale de la Santé a été utilisé afin d'organiser les résultats. Les résultats ont démontré que la recherche scientifique était orientée vers 
des handicaps spécifiques, parmi lesquels les blessés médullaires et la sclérose en plaques sont très présents. Des corrélations significatives ont été identifiées dépendantes du type de handicap et des facteurs environnementaux (par exemple le coût, l'accessibilité, l'environnement, l'information et l'aide sociale) mais aussi des facteurs personnels (par exemple l'âge, l'estime de soi, la dépression, la santé mentale). Les résultats confirment la nécessité de mener de futures recherches sur l'activité physique au sein des personnes handicapées.

MOTS CLES : activité physique, exercice, handicap, corrélats, déterminants.

\section{ФЗИЧЕСКАЯ ИНВАЛИДНОСТЬ И ФИЗИЧЕСКАЯ АКТИВНОСТЬ: ОБЗОР ЛИТЕРАТУРЫ НА ТЕМУ КОРРЕЛЯЦИИ И ВЗАИМОСВЯЗИ МЕЖДУ НИМИ}

(Аннотацця)

Целью данной статьи было изучение литературы, где отображены соотношение и взаимосвязь физической активности среди взрослых (в возрасте 16-65 лет) с ограниченными физическими возможностями. Электронный поиск был осуществлен таким образом, что отбирались исследовательские статьи, опубликованные с1980 по 2009 года. Было найдено 4189 статей; однако, только 57 из них отвечали всем определенным критериям. Они представляли семь групп инвалидности, включая перекрестную категорию с двумя или более видами инвалидности. В качестве структурной основы для обработки результатов была использована Международная классификация функционирования, ограничений деятельности и здоровья, разработанная Всемирной организацией здравоохранения. Результаты показали существенное ядро исследования, касающееся нескольких групп инвалидности, в том числе травмы спинного мозга и рассеянный склероз. Была выявлена значительная взаимосвязь с типом инвалидности и функционирования, а также с внешними факторами (например, расходы, доступность, окружающая среда, информация и социальная поддержка) и личностными (например, возраст, самостоятельность, депрессия, психическое здоровье).

КЛЮЧЕВЫЕ СЛОВА: физическая активность, упражнения, инвалидность, взаимосвязь, определения

\section{ACTIVIDAD FÍSICA Y DISCAPACIDAD FÍSICA: UNA REVISIÓN DE LA LITERATURA EN RELACIONES Y ASOCIACIONES}

(Resumen)

El propósito de este artículo fue analizar la literatura sobre correlaciones y asociaciones de la actividad física en adultos (edad 16-65 años) con discapacidad física. Las búsquedas electrónicas se realizaron para identificar artículos de investigación publicados desde 1980 hasta 2009. Fueron identificados los criterios específicos de inclusión en el estudio. La búsqueda obtuvo 4.189 artículos; sin embargo, sólo 57 cumplieron con todos los criterios especificados. Ellos representaban a siete grupos de discapacidad, incluyendo categorías con dos o más discapacidades. La Clasificación Internacional del Funcionamiento, la Discapacidad y la Salud, desarrollado por la Organización Mundial de la Salud, se utilizó como marco estructural para la organización de los resultados. Los resultados revelaron un núcleo sustancial de investigaciones relacionadas con unos pocos grupos de discapacidad, entre ellos las lesiones medulares y la esclerosis múltiple. No solo se identificaron correlaciones significativas en relación con el tipo de discapacidad y el funcionamiento, sino también entre los factores ambientales (por ejemplo, los costes, la accesibilidad, el medio ambiente construido, información y apoyo social) y factores personales 
(edad, ejercicio, autoeficacia, depresión, salud mental). Los resultados se discuten en relación con la realización de futuras investigaciones de actividad física en las personas con discapacidad.

PALABRAS CLAVE: Actividad fisica, ejercicio, discapacidad, correlaciones, determinantes.

\section{DEFICIÊNCIA FÍSICA E ACTIVIDADE FÍSICA: UMA REVISÃO DA LITERATURA SOBRE CORRELAÇÕES E ASSOCIAÇÕES}

(Resumo)

O objectivo do presente artigo foi analisar a revisão da literatura face às correlações e às associações da actividade Física entre adultos (idades 16-65 anos) com deficiência física. Uma pesquisa electrónica foi levada a cabo para identificar artigos publicados entre 1980 e 2009. Foram identificados critérios específicos de inclusão. A pesquisa produziu 4189 artigos, no entanto apenas 57 cumpriram todos os critérios de inclusão. Eles representavam sete grupos diferentes de deficiência, incluindo uma categoria cruzada com dois ou mais tipos de deficiência. A Classificação Internacional da Funcionalidade, Deficiência e Saúde desenvolvida pela Organização Mundial de Saúde foi utilizada como quadro de referência conceptual para a organização dos resultados. Os resultados demonstraram um núcleo substancial de pesquisa relacionado com poucos grupos de deficiência, entre os quais os traumatizados vertebro-medulares e as escleroses múltiplas. Foram encontradas correlações significativas entre tipo de deficiência e funcionalidade, mas também entre factores do envolvimento (ex: custos, acessibilidade, envolvimento construído, informação e suporte social) e (ex: idade, auto-eficácia do exercício, depressão e saúde mental). Os resultados são discutidos relativamente à condução futura de pesquisas na área da actividade física em pessoas com deficiência. 